\title{
The north-eastern Polish anorthosite massifs: petrological, geochemical and isotopic evidence for a crustal derivation
}

\author{
Janina Wiszniewska, ${ }^{1}$ Stefan Claesson, ${ }^{2}$ Holly Stein, ${ }^{3}$ Jacqueline Vander Auwera ${ }^{4}$ \\ and Jean-Clair Duchesne ${ }^{4 *}$ \\ ${ }^{1}$ Polish Geological Institute, Warsaw, Poland; ${ }^{2}$ Swedish Museum of Natural Sciences, Stockholm, Sweden; ${ }^{3}$ AIRIE Program, Colorado State \\ University, Fort Collins, USA; ${ }^{4}$ Géologie, Pétrologie et Géochime, University of Liège, Belgium
}

\begin{abstract}
Deeply buried 1.5 Ga Polish anorthosites, accessible only by bore holes, reveal diagnostic features of some massif-type anorthosites (polybarism, jotunitic parent magma), diapirically emplaced in the mid crust together with the rapakivi granites of the EW-trending Mazury complex, intruded along a major crustal discontinuity. Geochemical modelling and isotope data corroborate recent experimental work on the basaltic system in
\end{abstract}

dry conditions: the source rock of the parental magma is a gabbronorite, necessarily lying in the lower crust. Since no Archaean crust is known in the region, high initial ${ }^{188} 0 \mathrm{~s} /{ }^{187} \mathrm{Os}$ ratios for sulphide-oxide isochrons and negative $\varepsilon_{\mathrm{Nd}}$ values are best accounted for by melting a $\sim 2.0 \mathrm{Ga}$ mafic crust.

Terra Nova, 14, 451-460, 2002

\section{Introduction}

Diapiric emplacement is a now widely accepted process for most massive anorthosites (see References in Ashwal, 1993). Evidence of polybaric crystallization is demonstrated by the occurrence of high alumina orthopyroxene megacrysts (HAOM), shown experimentally to have equilibrated at lower crustal pressure (11-13 kbar) (Longhi et al., 1993), and brought to their final level of emplacement at depths corresponding to 3-5 kbar by diapirism (Berg, 1977; Barnichon et al., 1999).

Experimental data have also shown that a range of compositions from high alumina basalt (Fram and Longhi, 1992) to jotunite (Fe-Ti-P-rich hypersthene monzodiorite) (Vander Auwera et al., 1998b) can be possible parents to the noritic series of anorthosites and related rocks of the anorthosite, mangerite, charnockite and (rapakivi) granite (AMCG) suite. Recent data in the basaltic system in dry conditions at pressures up to $13 \mathrm{kbar}$ (Longhi et al., 1999) have constrained the composition of the source rocks of these parent magmas: a plagioclase + orthopyroxene + clinopyroxene-bearing source is required, and thus mafic granulites or gabbronorites from layered complexes are possible source

*Correspondence: J.-C. Duchesne, Géologie, Pétrologie et Géochimie Bat B20, Université de Liège, 4000 Sart Tilman, Belgique. Tel.: 32436622 55; fax: + 3243 6629 21; e-mail: jc.duchesne@ulg.ac.be rocks. It has also been recognized in the Nain plutonic series (Emslie et al., 1994; Hamilton et al., 1998), the Laramie Complex (Scoates and Chamberlain, 1997) or the Grenville Province (Higgins and van Breemen, 1992) that the anorthosite massifs coincide with structural weaknesses in the lithosphere which have channelled and facilitated the diapiric emplacement (Scoates and Chamberlain, 1997; Duchesne et al., 1999).

The anorthosite massifs of NE Poland are part of the Mazury Complex which was emplaced along an E-Wtrending lineament. The anorthosites show HAOM, characteristic of a polybaric evolution, and melts of the jotunite kindreds. These petrological diagnostic features point to a crustal origin, a conclusion corroborated by $\mathrm{Sm}-\mathrm{Nd}$ and $\mathrm{Re}-\mathrm{Os}$ isotopic data.

\section{Geological setting and petrology}

Two anorthosite massifs, the Suwalki and the Sejny massifs (Fig. 1), belong to the eastern part of the Mazury Complex (N. Poland), which is made up of a variety of (rapakivi-like) granites, emplaced around $1.5 \mathrm{Ga}$ (Claesson et al., 2001) in the crystalline basement of the East European Craton along an E-W fault zone (Kubicki and Ryka, 1982). They are overlain by a 580-1200-m-thick Phanerozoic sedimentary cover and have been explored by geophysics and drilling (Ryka and Podemski, 1998).

The $250-\mathrm{km}^{2}$ Suwalki massif shows in cross-section a domical structure whose centre is made up of anorthosites, with some norites and $\mathrm{Fe}-\mathrm{Ti}$ layered deposits, capped by gabbronorites and diorites. An Re-Os isochron age of $1559 \pm 37 \mathrm{Ma}$ has been obtained on sulphide and oxide minerals from the deposits (Stein et al., 1998; Morgan et al., 2000). Andesine plagioclase is the main rock-forming mineral, followed by orthopyroxene, clinopyroxene, Ti-magnetite and ilmenite. Apatite, spinel and titanite are accessories (Juskowiak, 1998) as well as sulphides (Wiszniewska, 1998). The smaller Sejny massif also comprises gabbroidic rocks, syenites and granitoids.

\section{New data on the geochemistry of} the anorthosites and related rocks

Petrological and geochemical characteristics of new samples coming from drill cores of the two massifs are reported here. Major and trace elements on whole rocks and on plagioclases are presented in Tables 1 and 2. An electron microprobe was also used for mineral analysis, particularly of zoned grains.

Anorthosites and norites have compositions typical of cumulate rocks. Anorthosites are essentially made up of plagioclase (An45-55) and accordingly their REE distributions (Fig. 2a) show strong positive anomalies $(\mathrm{Eu} /$ $\mathrm{Eu}^{*}$ up to 8.5 ) with large $[\mathrm{La} / \mathrm{Yb}]_{\mathrm{N}}$ ratios (30-60). The contents in elements incompatible with plagioclase, such as $\mathrm{Zr}, \mathrm{Nb}$ and transition elements, are low and mostly controlled by the 

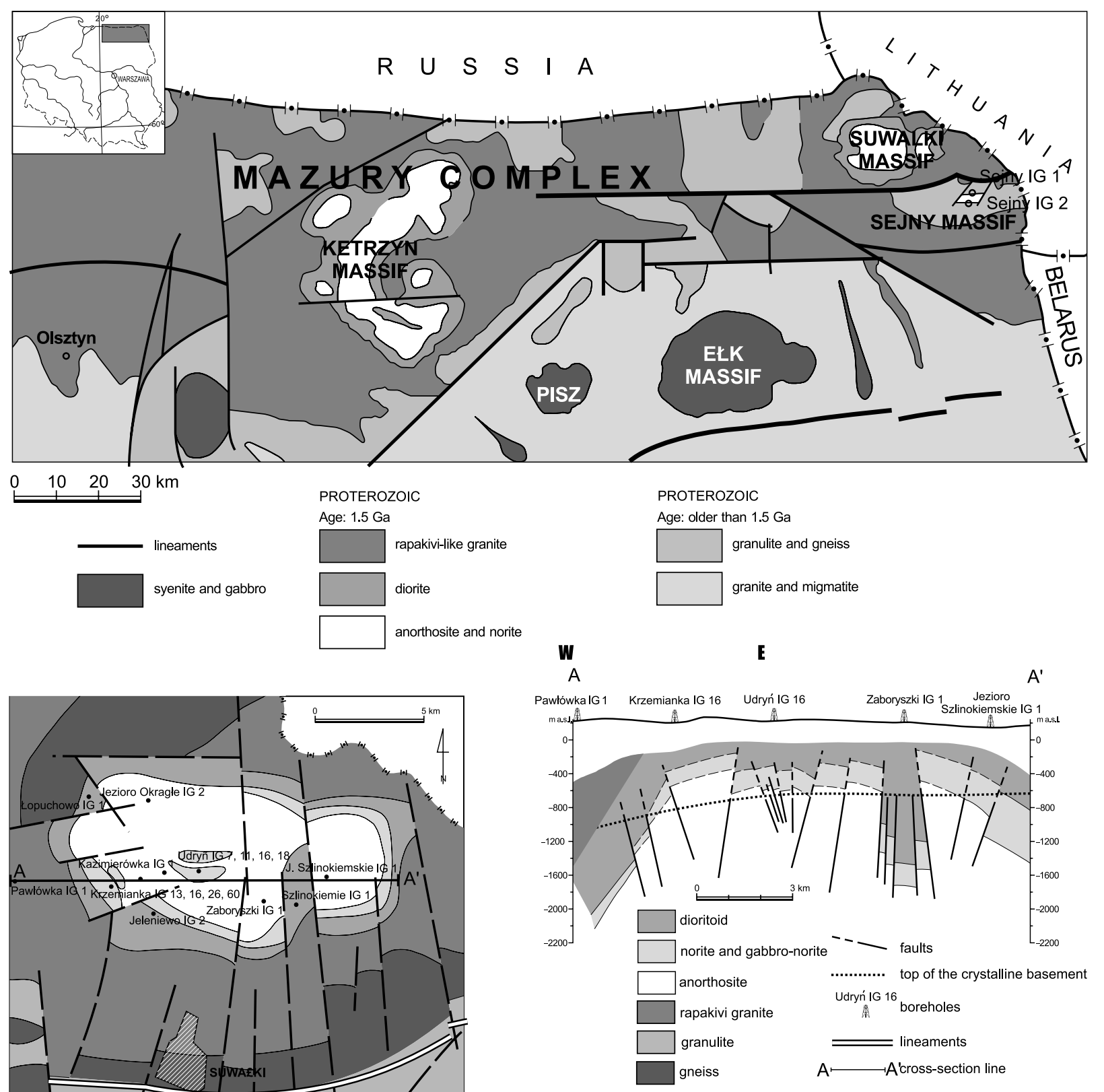

Fig. 1 The Mazury Complex and the anorthosite massifs. Top: schematic geological map of the Mazury Complex essentially made up of rapakivi and rapakivi-like granites, anorthosites and related rocks. The complex extends westwards some $100 \mathrm{~km}$ to the Baltic sea, and eastwards c. $30 \mathrm{~km}$ in Lithuania (Veisiejai Complex) and Belarus (Kapciamiestis massif) (Skridlaite et al. unpubl. obs.). Lower left: geological map of the Suwalki and Sejny anorthosites in NE Poland. Same legend as in lower right figure. The bore holes from which the samples studied here have been collected are indicated. Lower right: cross-section through the Suwalki anorthosite dome (after Juskowiak, 1998). Emplacement of bore holes indicated. Note the thickness of the sedimentary cover (from 600 to $900 \mathrm{~m}$ ).

mafic mineral content. REE span a relatively large interval of concentrations, which can be explained partly by fractional crystallization and partly by varying amounts of apatite crystallized from trapped liquid (sample P14 has the highest REE and $\mathrm{P}_{2} \mathrm{O}_{5}$ contents). Norite REE distributions
(Fig. 2b) display smaller positive anomalies $\left(\mathrm{Eu} / \mathrm{Eu}^{*} \approx 2\right)$ and $[\mathrm{La} / \mathrm{Yb}]_{\mathrm{N}}$ $\approx 8$ in agreement with a larger pyroxene content of the norite.

Besides these data, several other petrological and geochemical characteristics permit comparison with other anorthosite occurrences and partic- ularly with the Rogaland anorthosites, Norway (Duchesne, 1987; Duchesne et al., 1999). Several features point to similar petrogenetic processes and mechanisms of emplacement which suggest that both occurrences are derived from a crustal source. 
Table 1 Major (\%) and trace (p.p.m) element composition in anorthosites, norites, and jotunites

\begin{tabular}{|c|c|c|c|c|c|c|c|c|c|c|c|}
\hline & $\begin{array}{l}\text { Anorth } \\
\text { P-12 }\end{array}$ & $\begin{array}{l}\text { Anorth } \\
\text { P-13 }\end{array}$ & $\begin{array}{l}\text { Anorth } \\
\text { P-18 }\end{array}$ & $\begin{array}{l}\text { Anorth } \\
\text { P-14 }\end{array}$ & $\begin{array}{l}\text { Anorth } \\
\text { P-21 }\end{array}$ & $\begin{array}{l}\text { Norite } \\
\text { P-10 }\end{array}$ & $\begin{array}{l}\text { Norite } \\
\text { P-11 }\end{array}$ & $\begin{array}{l}\text { Norite } \\
\text { P-08 }\end{array}$ & $\begin{array}{l}\text { Norite } \\
\text { P-07 }\end{array}$ & $\begin{array}{l}\text { Jotunite } \\
\text { JW9718 }\end{array}$ & $\begin{array}{l}\text { Jotunite } \\
\text { JW974 }\end{array}$ \\
\hline $\mathrm{SiO}_{2}$ & 52.99 & 53.91 & 53.88 & 52.10 & 54.36 & 50.61 & 50.20 & 52.16 & 51.92 & 46.74 & 42.53 \\
\hline $\mathrm{TiO}_{2}$ & 0.23 & 0.11 & 0.20 & 0.12 & 0.26 & 0.36 & 0.27 & 0.33 & 0.39 & 2.26 & 3.45 \\
\hline $\mathrm{Al}_{2} \mathrm{O}_{3}$ & 26.91 & 27.46 & 27.33 & 28.40 & 26.64 & 24.94 & 23.48 & 19.81 & 18.72 & 16.33 & 15.19 \\
\hline $\mathrm{Fe}_{2} \mathrm{O}_{3}$ & 0.34 & 0.16 & 0.29 & 0.25 & 0.36 & 0.79 & 0.93 & 1.54 & 1.78 & 3.14 & 3.62 \\
\hline $\mathrm{FeO}$ & 1.30 & 0.62 & 1.11 & 0.95 & 1.39 & 3.02 & 3.57 & 5.90 & 6.83 & 12.04 & 13.67 \\
\hline $\mathrm{MnO}$ & 0.02 & 0.01 & 0.01 & 0.02 & 0.02 & 0.06 & 0.10 & 0.15 & 0.18 & 0.26 & 0.26 \\
\hline $\mathrm{MgO}$ & 0.58 & 0.16 & 0.22 & 0.52 & 0.28 & 1.97 & 3.79 & 5.57 & 6.48 & 4.46 & 5.40 \\
\hline $\mathrm{CaO}$ & 10.56 & 10.99 & 10.85 & 11.99 & 10.49 & 11.33 & 10.66 & 8.42 & 7.86 & 9.31 & 9.81 \\
\hline $\mathrm{Na}_{2} \mathrm{O}$ & 4.10 & 3.97 & 3.81 & 3.39 & 4.08 & 2.98 & 2.65 & 2.69 & 2.44 & 2.50 & 2.76 \\
\hline $\mathrm{K}_{2} \mathrm{O}$ & 0.61 & 0.67 & 0.73 & 0.54 & 0.86 & 0.50 & 0.48 & 0.67 & 0.69 & 0.52 & 0.50 \\
\hline $\mathrm{P}_{2} \mathrm{O}_{5}$ & 0.01 & 0.01 & 0.01 & 0.13 & 0.03 & 0.04 & 0.01 & 0.01 & 0.04 & 0.66 & 1.23 \\
\hline LOI & 1.37 & 1.34 & 0.51 & 1.03 & 0.66 & 2.48 & 2.39 & 2.58 & 1.47 & 0.34 & 0.18 \\
\hline Total & 99.16 & 99.49 & 99.07 & 99.54 & 99.58 & 99.41 & 98.93 & 100.49 & 99.56 & 99.89 & 100.12 \\
\hline U & 0.02 & 0.01 & 0.03 & 0.19 & 0.12 & 0.05 & 0.03 & 0.14 & 0.38 & 0.09 & 0.13 \\
\hline Th & 0.04 & 0.11 & 0.11 & 0.34 & 0.96 & 0.67 & 0.47 & 0.77 & 1.73 & 0.49 & 1.06 \\
\hline $\mathrm{Zr}$ & 3.8 & 1.9 & 4.7 & 2.2 & 29 & 27 & 13 & 20 & 40 & 96 & 79 \\
\hline $\mathrm{Hf}$ & 0.4 & 0.3 & 0.4 & 0.4 & 1.0 & 1.0 & 0.6 & 0.8 & 1.5 & & 1.7 \\
\hline $\mathrm{Zr} / \mathrm{Hf}$ & 9 & 5 & 12 & 6 & 28 & 27 & 21 & 24 & 27 & & 47 \\
\hline $\mathrm{Nb}$ & 0.29 & 0.53 & 0.63 & 1.26 & 2.61 & 2.38 & 1.27 & 2.14 & 3.80 & 10.20 & 10.71 \\
\hline Ta & 0.09 & 0.06 & 0.07 & 0.17 & 0.14 & 0.09 & 0.09 & 0.14 & 0.28 & 0.45 & 0.52 \\
\hline $\mathrm{Nb} / \mathrm{Ta}$ & 3 & 9 & 9 & 8 & 19 & 26 & 14 & 15 & 14 & 23 & 21 \\
\hline $\mathrm{Rb}$ & 5 & 4 & 4 & 6 & 5 & 7 & 6 & 7 & 13 & 7 & 7 \\
\hline $\mathrm{Sr}$ & 797 & 866 & 846 & 706 & 800 & 692 & 624 & 332 & 477 & 684 & 608 \\
\hline $\mathrm{Ba}$ & 286 & 301 & 379 & 214 & 515 & 242 & 178 & 168 & 282 & 510 & 319 \\
\hline $\mathrm{K} / \mathrm{Rb}$ & 1015 & 1401 & 1496 & 762 & 1532 & 586 & 697 & 750 & 427 & 662 & 570 \\
\hline $\mathrm{K} / \mathrm{Ba}$ & 18 & 19 & 16 & 21 & 14 & 17 & 22 & 33 & 20 & 8 & 13 \\
\hline V & 57 & 17 & 33 & 23 & 36 & 80 & 58 & 62 & 92 & 485 & 522 \\
\hline $\mathrm{Cr}$ & 71 & 80 & 160 & 71 & 131 & 220 & 154 & 239 & 367 & & \\
\hline $\mathrm{Zn}$ & 28 & 2 & 13 & 3 & 2 & 43 & 33 & 71 & 112 & 198 & 244 \\
\hline Co & 7 & 2 & 4 & 4 & 5 & 16 & 20 & 24 & 42 & 67 & 66 \\
\hline $\mathrm{Cu}$ & 15 & 4 & 10 & 17 & 12 & 38 & 14 & 52 & 53 & & \\
\hline $\mathrm{Ga}$ & 20 & 20 & 21 & 25 & 22 & 20 & 17 & 12 & 20 & 23 & 28 \\
\hline $\mathrm{Pb}$ & 3 & 7 & 4 & 14 & 7 & 4 & 2 & 5 & 7 & 6 & 8 \\
\hline Y & 1 & 1 & 2 & 7 & 3 & 6 & 5 & 4 & 8 & 25 & 43 \\
\hline La & 4.3 & 4.6 & 5.8 & 20.7 & 15.0 & 7.3 & 5.2 & 5.2 & 10.0 & 34 & 48 \\
\hline $\mathrm{Ce}$ & 6.8 & 8.0 & 10.3 & 37.1 & 25.2 & 13.8 & 10.5 & 9.9 & 19.6 & 72 & 112 \\
\hline $\operatorname{Pr}$ & 0.7 & 0.9 & 1.1 & 4.0 & 2.7 & 1.6 & 1.2 & 1.1 & 2.1 & 10.1 & 16.8 \\
\hline $\mathrm{Nd}$ & 2.7 & 3.1 & 3.7 & 15.8 & 9.9 & 6.3 & 4.5 & 4.6 & 8.6 & 42 & 71 \\
\hline Sm & 0.5 & 0.3 & 0.7 & 2.6 & 1.6 & 1.1 & 0.8 & 0.7 & 1.5 & 7.6 & 14.7 \\
\hline $\mathrm{Eu}$ & 0.8 & 0.8 & 1.0 & 1.8 & 1.5 & 0.8 & 0.6 & 0.5 & 0.8 & 2.4 & 3.7 \\
\hline $\mathrm{Gd}$ & 0.32 & 0.25 & 0.56 & 2.17 & 1.10 & 1.14 & 0.74 & 0.66 & 1.32 & 6.61 & 12.74 \\
\hline $\mathrm{Tb}$ & 0.04 & & & 0.30 & 0.14 & 0.21 & 0.11 & 0.12 & 0.20 & 0.85 & 1.66 \\
\hline Dy & 0.23 & 0.16 & 0.31 & 1.45 & 0.60 & 0.94 & 0.64 & 0.59 & 1.25 & 4.60 & 8.18 \\
\hline Ho & 0.05 & 0.04 & 0.07 & 0.31 & 0.14 & 0.21 & 0.16 & 0.15 & 0.31 & 0.89 & 1.61 \\
\hline Er & 0.10 & 0.08 & 0.14 & 0.63 & 0.26 & 0.52 & 0.39 & 0.37 & 0.79 & 2.44 & 3.77 \\
\hline $\mathrm{Tm}$ & & & & 0.08 & & & 0.07 & 0.06 & 0.13 & 0.32 & 0.51 \\
\hline $\mathrm{Yb}$ & 0.08 & 0.07 & 0.11 & 0.46 & 0.15 & 0.50 & 0.40 & 0.37 & 0.79 & 2.30 & 2.82 \\
\hline Lu & & & & 0.04 & 0.02 & 0.08 & 0.07 & & 0.10 & 0.33 & 0.37 \\
\hline $\mathrm{La} / \mathrm{Yb} \mathrm{n}$ & 35 & 45 & 35 & 29 & 63 & 9 & 8 & 9 & 8 & 10 & 11 \\
\hline $\mathrm{Eu} / \mathrm{Eu}^{*}$ & 6.32 & 8.59 & 4.73 & 2.32 & 3.50 & 2.06 & 2.27 & 2.06 & 1.76 & 1.04 & 0.83 \\
\hline $\mathrm{Mg} /(\mathrm{Mg}+\mathrm{Fe})($ atom $)$ & 0.39 & 0.27 & 0.22 & 0.44 & 0.23 & 0.49 & 0.61 & 0.58 & 0.58 & 0.35 & 0.36 \\
\hline $\mathrm{FeOt} / \mathrm{MgO}+\mathrm{FeOt}$ & 0.73 & 0.83 & 0.86 & 0.69 & 0.86 & 0.65 & 0.54 & 0.57 & 0.57 & 0.77 & 0.76 \\
\hline Peral (mol\%) & & & & & & & & & & 0.76 & 0.66 \\
\hline Agp (mol\%) & & & & & & & & & & 0.29 & 0.33 \\
\hline Sat T zircon ${ }^{\circ} \mathrm{C}$ & & & & & & & & & & 650 & 599 \\
\hline Sat T apatite ${ }^{\circ} \mathrm{C}$ & & & & & & & & & & 823 & 848 \\
\hline \multicolumn{12}{|c|}{ CIPW normative composition (wt $\%$ ) } \\
\hline An & 60 & 62 & 61 & 67 & 60 & 68 & 69 & 64 & 65 & 60 & 54 \\
\hline Feldspar & 91 & 92 & 90 & 91 & 91 & 81 & 76 & 67 & 63 & 56 & 54 \\
\hline Mafic & 4 & 2 & 3 & 4 & 4 & 12 & 18 & 27 & 31 & 42 & 45 \\
\hline
\end{tabular}

Sample location: P-12: Krzemianka, P-13: Kazimierowka; P-18, P-21: Udryn; P-14: Lopuchowo; P-10, P-11, P-8, P-7, JW9718: Sejny; JW974: Suwalki. Analytical methods: Major elements by XRF on Li-borate discs; trace elements by ICP-MS (Vander Auwera et al., 1998a) or by XRF on pressed powders. $\mathrm{FeO}$ calculated on the basis of $\mathrm{Fe}_{2} \mathrm{O}_{3}=0.19 \mathrm{Fe}_{2} \mathrm{O}_{3}$ t (following Kress and Carmichael (1991) at $3 \mathrm{kbar}$ and $1160{ }^{\circ} \mathrm{C}$ ). 
Table 2 Major and trace element composition of plagioclase

\begin{tabular}{lrrrrr}
\hline & U16 & Krz60 & Jez02 & IP-G & IP-B \\
\hline in \% & & & & & \\
$\mathrm{CaO}$ & 10.99 & 10.80 & 11.31 & 10.80 & 10.32 \\
$\mathrm{~K}$. & 0.54 & 0.51 & 0.56 & 0.57 & 0.56 \\
in p.p.m. & & & & & \\
$\mathrm{Fe}$ & 3287 & 5455 & 7203 & 4755 & 5874 \\
$\mathrm{Ti}$ & 247 & 326 & 583 & 342 & 456 \\
$\mathrm{Ba}$ & 268 & 265 & 302 & 285 & 261 \\
$\mathrm{Sr}$ & 884 & 840 & 797 & 885 & 880 \\
$\mathrm{Rb}$ & 4.9 & 4.8 & 5.2 & 3.6 & 3.6 \\
$\mathrm{~Pb}$ & 2.2 & 2.2 & 3.3 & 6.2 & 2.3 \\
$\mathrm{La}$ & 7.2 & 6.2 & 6.1 & 2.9 & 2.6 \\
$\mathrm{Ce}$ & 9.5 & 7.1 & 8.0 & 4.4 & 4.0 \\
$\mathrm{Pr}$ & & & & 0.57 & 0.48 \\
$\mathrm{Nd}$ & 4.4 & 2.8 & 3.1 & 1.7 & 1.5 \\
$\mathrm{Sm}$ & 0.65 & 0.33 & 0.44 & 0.33 & 0.33 \\
$\mathrm{Eu}$ & 0.63 & 0.69 & 0.76 & 0.58 & 0.56 \\
$\mathrm{Gd}$ & 0.62 & 0.25 & 0.40 & 0.30 & 0.33 \\
$\mathrm{~Tb}$ & 0.09 & 0.03 & 0.05 & & 0.06 \\
$\mathrm{Dy}$ & 0.42 & 0.16 & 0.25 & 0.22 & 0.19 \\
$\mathrm{Ho}$ & 0.08 & 0.03 & 0.05 & 0.03 & \\
$\mathrm{Er}$ & 0.24 & 0.10 & 0.14 & 0.09 & 0.10 \\
$\mathrm{Yb}$ & 0.19 & 0.08 & 0.13 & 0.08 & 0.10 \\
$\mathrm{Lu}$ & & & & 0.01 & 0.01 \\
$\mathrm{An}($ wt\%) & 55 & 54 & 56 & 54 & 51 \\
\hline
\end{tabular}

U16, Krz60, JezO2 were separated by physical methods from rocks of Udryn, Krzemianka and Jezioro Okragle drill cores, respectively. IP-G, IP-B are iridescent plagioclase megacrysts from Suwalki.

High-alumina orthopyroxene megacrysts. Megacrysts of orthopyroxene, up to $10 \mathrm{~cm}$ long, are found in coarse-grained anorthosites (An6266). They show evidence of deformation by kinking and locally by granulation (polygonization). Inversely zoned plagioclase grains are common in the deformed parts of the megacryst, and lamellae of plagioclase can locally be observed in the (100) planes of the host pyroxene (Fig. 3). The host orthopyroxene is En 68 and has a relatively low $\mathrm{Al}_{2} \mathrm{O}_{3}$ content of $2-3 \%$. The plagioclase granules vary from An76 in the centre to An94 at the rim (inverse zoning), in contrast with the plagioclase of the anorthosite which is less calcic (An66). Similar textures are observed in most massif-type anorthosites (see Ashwal, 1993), and particularly in the Rogaland anorthosites (Maquil and Duchesne, 1984). Following Emslie (1975), the plagioclase lamellae and granules are produced by an exsolution process during decreasing temperature and pressure, and are locally strain-activated. The original $\mathrm{Al}_{2} \mathrm{O}_{3}$ content of the orthopyroxene megacrysts is strongly pressure dependent (Longhi et al., 1993). In the present case, due to extensive external granule exsolution, no reintegration of the exsolved products in the host mineral to reconstruct the primary composition of the megacrysts is possible. Therefore, the depth of formation of the megacrysts is still to be ascertained but its value is certainly higher than the depth of final emplacement.

Iridescent plagioclase megacrysts. Fragments up to $10 \mathrm{~cm}$ in size of granulated iridescent plagioclase with blue, green and purple colours are commonly found embedded in an anorthosite matrix with the characteristic violet colour. Evidence of deformation of the megacrysts are curved twin planes and polygonized (granulated) margins. The plagioclase crystals are crowded with minute needles of rutile, $\mathrm{Fe}-\mathrm{Ti}$ oxides, and antiperthite exsolutions. They also locally contain association of very small pyroxene and oxide grains that possibly result from the crystallization of melt inclusions. Compositions of iridescent plagioclase are given in Table 2. They show high $\mathrm{Sr}$ contents (c. 900 p.p.m.) and An content c. $52-55 \%$. Such compositions are typical of massif-type anorthosite plagioclase megacrysts and contrast with plagioclase from layered intrusions, which, as pointed out by Emslie (1985), have Sr contents less than 500 p.p.m. Similar megacrysts are found associated with high-alumina orthopyroxene megacrysts in Rogaland massive anorthosites (Duchesne, 1987). Their REE contents are compared to the present megacrysts in Fig. 2(d). The overall contents fall in the same range of values, but with higher positive Eu anomalies and $\mathrm{La} / \mathrm{Yb}$ ratios than in the Suwalki anorthosites. Both differences can be explained by mixing small amounts (2-3\%) of jotunitic melt (see below) with the Rogaland plagioclase with the lowest REE content. Due to the low REE contents of the plagioclase, small inclusions of relatively REE-rich material, such as the melt inclusions observed here, strongly influence the bulk composition of the megacrysts.

Jotunitic chilled melts. Fine-grained $\mathrm{Fe}-\mathrm{Ti}$-P-rich jotunites have been sampled and analysed (Table 1). Petrographically, they show apatite crystals with high aspect ratios, which are disseminated together with small rounded $\mathrm{Fe}-\mathrm{Ti}$ oxide grains in all silicate minerals, a texture characteristic of chilled rocks (Demaiffe and Hertogen, 1981; Wiebe, 1984; Duchesne and Hertogen, 1988; Vander Auwera et al., 1998). Two samples slightly different in compositions are presented here: JW97-18 is made up of an unzoned plagioclase (An63), low$\mathrm{Ca}$ pyroxene $(\mathrm{mg} \#=59)$, high-Ca pyroxene $(\mathrm{mg} \#=74)$, apatite, $\mathrm{Fe}-\mathrm{Ti}$ oxides and accessory biotite; JW97-4 contains the same minerals, with plagioclase An54 and slightly more evolved pyroxenes $(\mathrm{mg} \#=56$ and 70 , respectively). The chemical compositions of these two jotunitic melts are reported in Table 1. Both rocks are characteristically high in $\mathrm{Fe}$ (up to $19.8 \% \mathrm{Fe}_{2} \mathrm{O}_{3} \mathrm{t}$ ), $\mathrm{Ti}$ (up to $3.45 \% \mathrm{TiO}_{2}$ ) and $\mathrm{P}$ (up to $1.2 \% \mathrm{P}_{2} \mathrm{O}_{5}$ ). The REE distributions (Fig. 2d) are moderately differentiated $\left.(\mathrm{La} / \mathrm{Yb}]_{\mathrm{N}} \approx 10\right)$ and do not show significant Eu anomalies. These geochemical characteristics are similar to Rogaland jotunites as shown in Fig. 2(d). On variation diagrams (Fig. 4) displaying the jotunite liquid line of descent (Vander Auwera et al., 1998b), JW97-18 plots close to the primitive jotunites defined in Rogaland; JW97-4, although somewhat less 

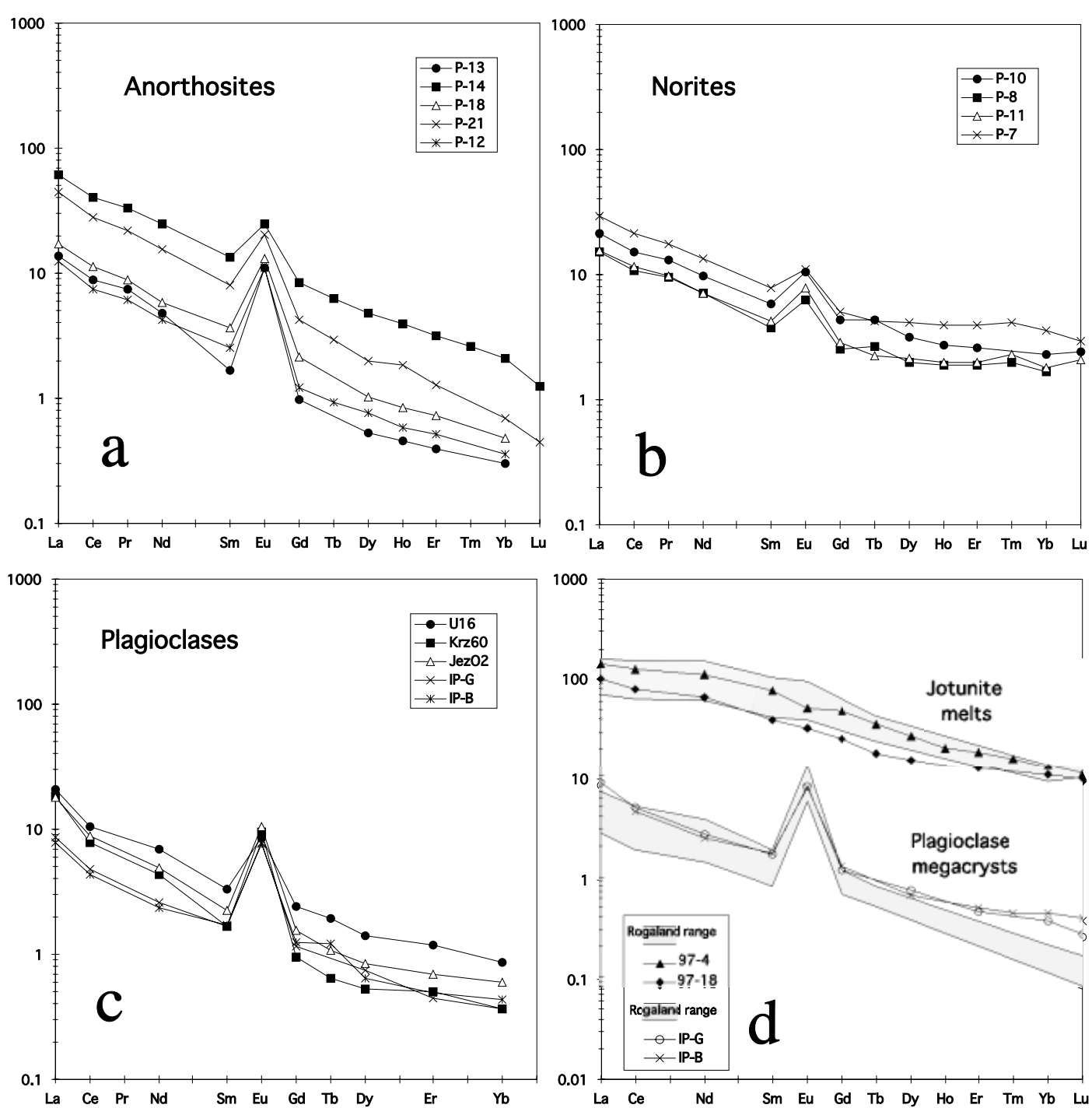

Fig. 2 Chondrite-normalized REE distributions (data from Tables 1 and 2) in (a) anorthosites, (b) norites, (c) iridescent plagioclase megacrysts and plagioclase separated from norites, and (d) REE in iridescent plagioclase megacrysts and jotunites compared to composition of similar materials from Rogaland.

evolved, has many common features with high-alumina basalts from Laramie and Maloin (Kolker et al., 1991).

\section{Jotunites as parental magma}

The first steps of crystallization of the two fine-grained jotunitic samples, JW97-4 and JW97-18, have been modelled using the MELTS algorithm (Ghiorso and Sack, 1995). The $\mathrm{fO}_{2}$ and pressure were set at FMQ and $3 \mathrm{kbar}$, respectively, as these are plausible conditions for anorthosite crystallization (e.g. Ashwal, 1993; Vander Auwera and Longhi, 1994). Results are shown in Table 3. In the first two steps, the calculated compositions of liquidus plagioclase and near liquidus low-Ca pyroxene (in JW97-4: first An68, then An60 and En65, and in JW97-18: first An70, then An59 and En58) are in the range of the observed compositions. In both modelling, whitlockite crystallizes instead of apatite because anhydrous crystallization has been imposed. Whitlockite crystallization is somewhat delayed $\left(1160{ }^{\circ} \mathrm{C}\right)$ in JW97-18, as is the case in primitive jotunites, but it appears at the liquidus $\left(1200{ }^{\circ} \mathrm{C}\right)$ of JW97-4, suggesting that some apatite accumulated in these samples. A Ti-rich phase also crystallizes in both sequences and a low-Ca pyroxene has a relatively long interval of crystallization, in agreement with the widespread occurrence of orthopyroxene in the anorthosite. The good agreement between observed and calculated phase compositions as well as the similar order of appearance of crystallizing phases corroborate the hypothesis that these samples represent parent magmas.

The REE contents of liquids in equilibrium with plagioclase have been calculated using appropriate partition coefficients (Vander Auwera et al., 1998b) and REE data acquired on mineral separates (Table 2). Except 


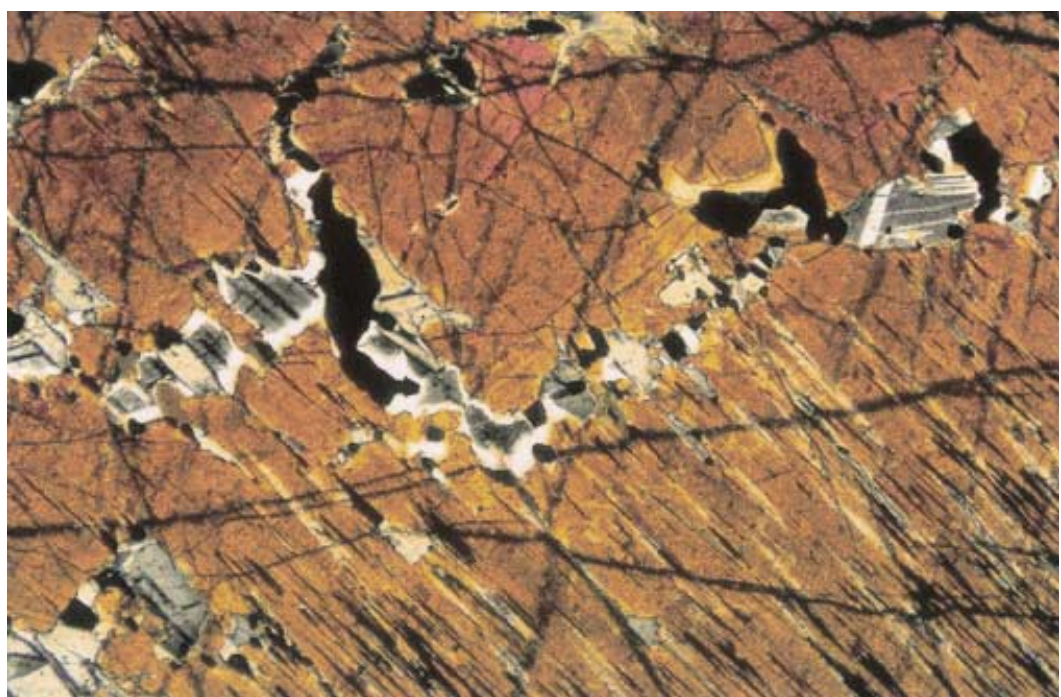

Fig. 3 Highly strained (kinked and polygonized) zone of a high-alumina orthopyroxene megacryst $(\mathrm{HAOM})$. Grains of inversely zoned plagioclase $(250-1000 \mu \mathrm{m})$ associated with $\mathrm{Fe}-\mathrm{Ti}$ oxide minerals are aligned along kink planes grossly perpendicular to the 100 plane of the HAOM. In the lower part of the field, plagioclase exsolutions, locally connected to plagioclase granules, are still visible. Crossed polars. Width of view: $3.7 \mathrm{~mm}$.

Table 3 Modelling the first crystallization steps of jotunitic liquids through the MELTS algorithm

\begin{tabular}{ll}
\hline$T\left({ }^{\circ} \mathrm{C}\right)$ & Crystallizing phases \\
\hline $\begin{array}{l}\text { Sample JW97.4 } \\
1200\end{array}$ & An68Ab32 - Whitlockite \\
1170 & An60Ab390r1 - Whitlockite - Pigeonite (Wo9En65Fs26) \\
1130 & An46Ab510r3 - Whitlockite - Pigeonite (Wo14En55Fs31) - Augite (Wo38En43Fs19) \\
& - Spinel (Mgt33Sp22Uvsp44) \\
$\begin{array}{l}\text { Sample JW97.18 } \\
1210\end{array}$ & An70Ab290r1 \\
1160 & An59Ab400r1 - Whitlockite - Pigeonite (Wo9En58Fs33) \\
1110 & An50Ab470r3 - Whitlockite - Augite (Wo37En35Fs28) - Spinel (Mgt39Sp14Uvsp47) \\
\hline
\end{tabular}

for $\mathrm{Eu}$, which is not considered because it is also controlled by the $f \mathrm{O}_{2}$, the calculated liquids have REE patterns in the range of those of the jotunitic samples (Fig. 5). This observation gives further support to a jotunitic parent magma.

\section{Jotunites as crustal derivates}

It has been shown by Longhi et al. (1999) on the basis of experimental data in the basaltic system from $1 \mathrm{~atm}$ to $13 \mathrm{kbar}$ in dry conditions that jotunite melts can evolve by fractional crystallization at pressure $<4$ kbar, with or without contamination by acidic material, to produce the AMCG suite. The petrological and not be found in the mantle (except close to Moho), it must be considered as crustal.

\section{Sm-Nd and Re-0s evidence for a crustal origin}

$\mathrm{Sm}-\mathrm{Nd}$ isotope data for anorthosite, norite and jotunite (including JW97-4 and 97-18) from the NE Polish anorthosites are shown in Table 4 and in an $\varepsilon_{\mathrm{Nd}}$-time evolution diagram in Fig. 6. The anorthosite samples have low $\mathrm{Sm}$ and $\mathrm{Nd}$ concentrations of $0.3-$ 0.7 and 2-5 p.p.m., respectively, and low ${ }^{147} \mathrm{Sm} /{ }^{144} \mathrm{Nd}$ ratios of $0.08-0.10$, reflecting the composition of the plagioclase, while corresponding values for jotunite and norite are 722 p.p.m., $40-126$ p.p.m and $0.11-$ 0.12 . Depleted mantle model ages (DePaolo, 1983) are between 1.9 and $2.3 \mathrm{Ga} . \varepsilon_{\mathrm{Nd}}$ values calculated at $1.5 \mathrm{Ga}$ range from -2 to -5 .

The Sm-Nd results clearly demonstrate that the anorthosite massifs are not composed entirely of materials directly derived from a 1.5-Ga mantle source. The source is either older continental crust, or a mixture between mantle and older crustal materials. In the latter case, this crustal material must be older than the obtained model ages, in all likelihood Archaean. However, there are no indications of the existence of Archaean crust in this region. On the contrary, a regional survey of the Precambrian crystalline basement of the East European (Claesson et al., 2001), and a reconnaissance $\mathrm{Nd}$ isotope investigation of various rock types from all major lithotectonic units in the Precambrian crystalline basement of north-eastern Poland (Claesson and Ryka, 1999) indicate that this entire crustal region is Palaeoproterozoic with $\mathrm{Nd}$ model ages of between 1.9 and $2.3 \mathrm{Ga}$. Our preferred interpretation of our $\mathrm{Nd}$ model ages is therefore that the NE Polish anorthosites are derived from Palaeoproterozoic continental crust, and that the $\mathrm{Nd}$ model ages approximate the age of this crust.

The $\mathrm{Nd}$ model ages reported here form a distinct group, but do nevertheless scatter significantly. Some scatter must be ascribed to the $\mathrm{Sm} / \mathrm{Nd}$ fractionation caused by the melting which formed the Suwalki magmas, and following crystalliza- 

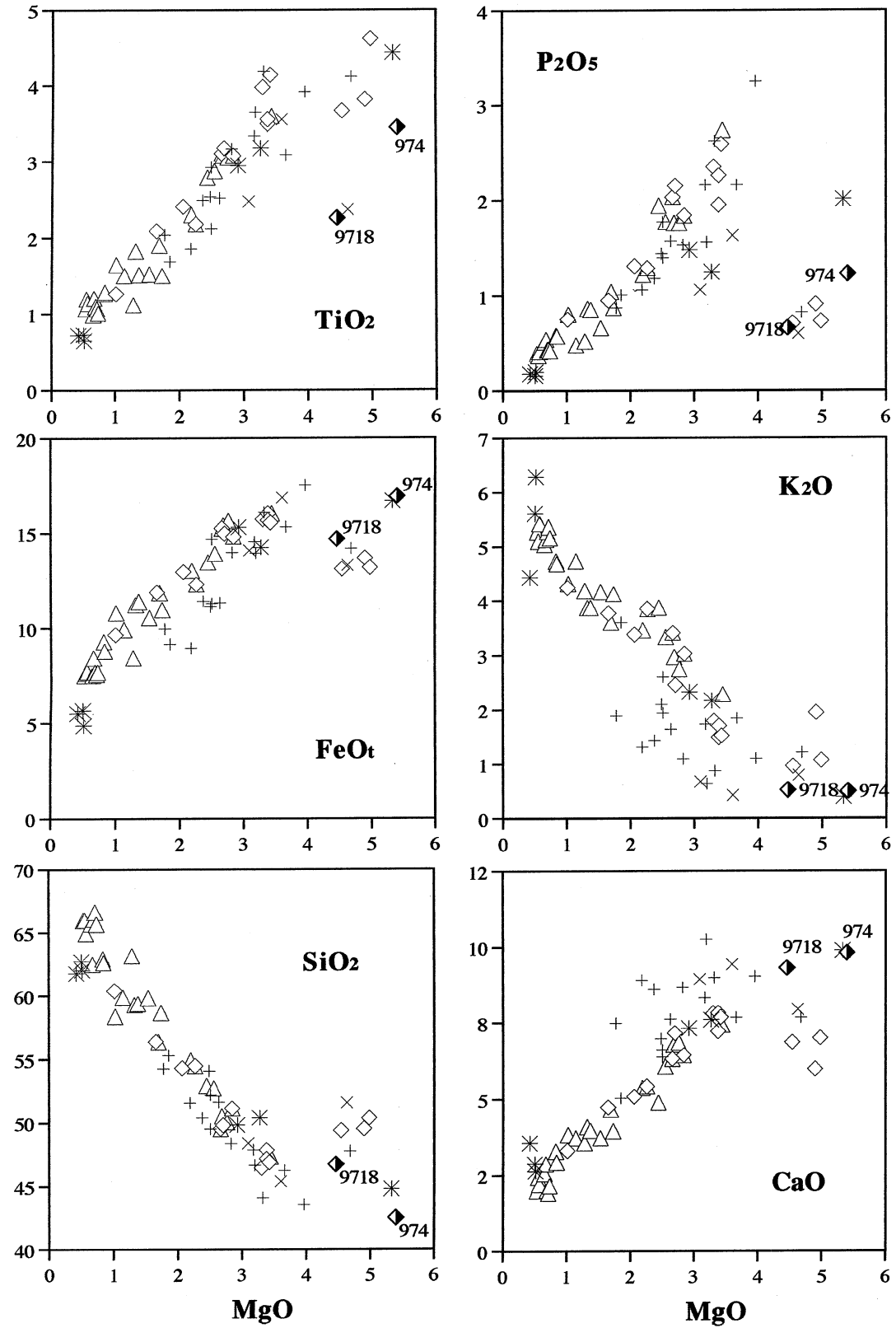

Fig. 4 Variation diagrams comparing the Polish chilled rocks to the liquid line of descent of the Rogaland jotunites and other occurrences. Legend: half-filled diamond: Suwalki-Sejny chilled rocks; +: Grenville occurrences (Owens et al., 1993); ×: Nain (Wiebe, 1979; Emslie et al., 1994); *: Maloin (Kolker et al., 1991; Mitchell et al., 1996); open diamond: primitive and evolved jotunite from Rogaland (Vander Auwera et al., 1998b); open triangle: Tellnes dyke series (Wilmart et al., 1989; Vander Auwera et al., 1998b).

tion and separation of cumulate. In particular, the $\mathrm{Nd}$ model ages for the anorthosites, which have $\mathrm{Sm} / \mathrm{Nd}$ ratios significantly lower than the $\mathrm{Sm} / \mathrm{Nd}$ ratios in the parent materials, should be interpreted as minimum ages for this material. However, if this were the sole cause tion of -5 to -6 , this would depend on assumed concentrations requiring that the samples with the least negative $\varepsilon_{\mathrm{Nd}}$ value contain more than $50 \%$ crustal material. This is difficult to reconcile with the geochemical characteristics of the jotunite melts. We therefore suggest that the scatter is mainly caused by isotopic inhomogeneities in a crustal source material.

The magmatic sulphides and oxides from the Suwalki massif provided the first Re-Os evidence used to suggest a possible crustal origin for anorthosite (Stein et al., 1998; Morgan et al., 2000). The proposed crustal origin for anorthosite was subsequently corroborated in a Re-Os study of the Rogaland anorthosite complex in southern Norway (Schiellerup et al., 2000). Subsequent modelling, however, leaves open the possibility that sulphide and silicate may be of different origin (Hannah and Stein, 2002). At Suwalki, high ${ }^{187} \mathrm{Os} /{ }^{188}$ Os initial ratios (e.g. $1.16 \pm 0.06$ ) for several deposits require a crustal source for the Os in sulphides. Given the Proterozoic age for the Suwalki massif, these ${ }^{187} \mathrm{Os} /{ }^{188}$ Os ratios clearly indicate involvement of crustal rocks in the genesis of the sulphide-bearing anorthosite massif. Morgan et al. (2000) suggest that a ${ }^{187} \mathrm{Re} /{ }^{188} \mathrm{Os}$ of $\sim 140$ in the Suwalki source accommodates the $\sim 2.0 \mathrm{Ga}, \mathrm{Nd}$ model ages, noting that ratios of $\sim 140$ may be found in a crust with a mafic component. These Re-Os data may be used to support a crustal origin for Suwalki.

\section{Conclusions}

The NE Polish anorthosites, which are part of the Mazury Complex, show typical petrological and geochemical characteristics of massif-type anorthosites, particularly occurrence of HAOM, of iridescent plagioclase megacrysts and of jotunite chilled rocks. Geochemical modelling points to a parental magma of jotunite composition, and phase diagrams constrain the gabbronoritic nature of the source rock in the lower crust. Negative $\varepsilon_{\mathrm{Nd}}$ values between -2 and -5 at the age of intrusion $(1.5 \mathrm{Ga})$ and high ${ }^{187} \mathrm{Os} /$ ${ }^{188}$ Os initial ratios (1.16) are consistent with $\mathrm{a} \sim 2.0 \mathrm{Ga}$ sulphide-bearing mafic crustal source. 


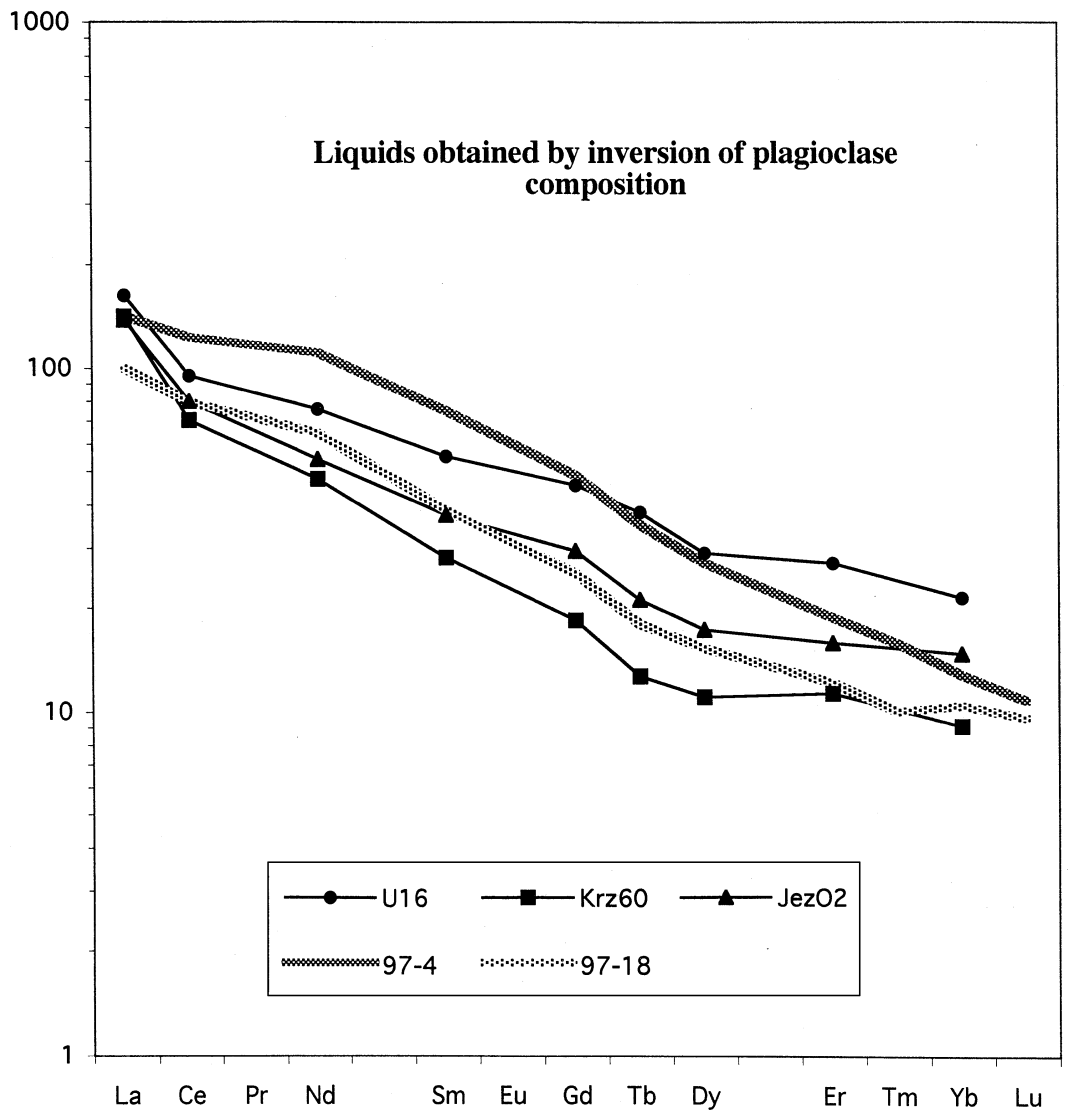

Fig. 5 REE distributions calculated by inversion of the plagioclase composition separated from norites and compared to jotunite compositions (JW97-4 and 9718). Note that $\mathrm{Eu}$ is not considered because of the unknown control of the $f \mathrm{O}_{2}$ on the distribution coefficient.

\section{References}

Ashwal, L.D., 1993. Anorthosites. Springer, Berlin.

Barnichon, J.-D., Havenith, H., Hoffer, B., Charlier, R., Jongmans, D. and Duchesne, J.C., 1999. The deformation of the Egersund Ogna massif, South Norway: Finite Element modelling of diapirism. Tectonophysics, 303, 109-130.

Berg, J.H., 1977. Dry granulite mineral assemblages in the contact aureole of the Nain Complex, Labrador. Contrib. Mineral. Petrol., 64, 32-52.

Claesson, S., Bibikova, E.V., Bogdanova, S.V. and Gorbatschev, R., 2001. Isotopic evidence of Paleoproterozoic accretion in the basement of the East European Craton. Tectonophysics, 319, 1-18.

Claesson, S. and Ryka, W., 1999. Nd model ages of the Precambrian crystalline basement of NE Poland. In: Between EUROBRIDGE and TESZ. 7th EUROBRIDGE Workshop, May 1999, Suwalki,

Table $4 \mathrm{Nd}$ isotope data from NE Polish anorthosites and related rocks

\begin{tabular}{|c|c|c|c|c|c|c|c|c|}
\hline Sample & Rock type & $\begin{array}{l}\text { Sm } \\
\text { (p.p.m) }\end{array}$ & $\begin{array}{l}\text { Nd } \\
\text { (p.p.m) }\end{array}$ & ${ }^{147} \mathrm{Sm} /{ }^{144} \mathrm{Nd}$ & ${ }^{143} \mathrm{Nd} /{ }^{144} \mathrm{Nd}$ & \pm & $\begin{array}{l}\mathrm{T}_{\mathrm{DM}}{ }^{*} \\
\text { (Ga) }\end{array}$ & $\begin{array}{l}\mathcal{E}_{\mathrm{Nd}} \dagger \\
(1.5 \mathrm{Ga})\end{array}$ \\
\hline 4.2 Krzemianka IG 13 & Anorthosite & 0.39 & 2.50 & 0.0949 & 0.511506 & 0.000009 & 1.97 & -2.5 \\
\hline 4.3 Krzemianka IG 26 & Anorthosite & 0.73 & 4.45 & 0.0992 & 0.511431 & 0.000008 & 2.15 & -4.8 \\
\hline 4.4 Jeleniewo IG 2 & Anorthosite & 0.31 & 2.10 & 0.0884 & 0.511411 & 0.000008 & 1.99 & -3.1 \\
\hline 4.9 Szlinokiemie IG 1 & Anorthosite & 0.36 & 2.41 & 0.0897 & 0.511448 & 0.000008 & 1.96 & -2.7 \\
\hline W15 Jez. Okr. IG 2 & Anorthosite & 0.82 & 4.91 & 0.1006 & 0.511458 & 0.000006 & 2.14 & -4.6 \\
\hline W19 Udryn IG7 & Anorthosite & 0.81 & 4.96 & 0.0987 & 0.511461 & 0.000016 & 2.06 & -3.5 \\
\hline W23 Udryn IG16 & Anorthosite & 0.33 & 2.26 & 0.0896 & 0.511443 & 0.000020 & 1.97 & -2.7 \\
\hline W26 Udryn IG18 & Anorthosite & 0.31 & 2.20 & 0.0862 & 0.511404 & 0.000017 & 1.96 & -2.8 \\
\hline 4.8 Zaboryszki IG 1 & Norite & 22.9 & 126 & 0.1099 & 0.511512 & 0.000004 & 2.25 & -5.3 \\
\hline JW 97-4 & Jotunite & 14.0 & 69.4 & 0.1217 & 0.511672 & 0.000003 & 2.28 & -4.4 \\
\hline JW 97-4 repeat & & 14.1 & 69.9 & 0.1215 & 0.511675 & 0.000010 & 2.27 & -4.3 \\
\hline JW 97-18 & Jotunite & 7.50 & 39.9 & 0.1134 & 0.511628 & 0.000005 & 2.15 & -3.7 \\
\hline JW 97-18 repeat & & 7.50 & 40.2 & 0.1127 & 0.511646 & 0.000010 & 2.11 & -3.2 \\
\hline 4.1 Udryn IG 11 & Jotunite & 14.6 & 79.7 & 0.1108 & 0.511537 & 0.000003 & 2.24 & -5.0 \\
\hline BCR-1 & & 6.59 & 28.75 & 0.1385 & 0.512633 & 0.000005 & & \\
\hline BCR-1 repeat & & 6.64 & 28.94 & 0.1386 & 0.512639 & 0.000010 & & \\
\hline
\end{tabular}

The samples were analysed on a Finnigan MAT 261 TIMS using total spiking with a mixed ${ }^{149} \mathrm{Sm} /{ }^{150} \mathrm{Nd}$ spike. The analyses were made over an extended period of time, during which both the chemical and the mass spectrochemical procedures were modified several times. The mass spectrometer was operated in both static and multidynamic mode. A conservative estimate of the reproducibility (external precision) for most samples, based on repeated runs of the La Jolla Nd standard, is \pm 40 p.p.m. (0.000020), while the reproducibility for 'JW97-4 repeat' and 'JW 97-18 repeat' was 25 p.p.m. The internal precision was always better than, or similar to, the reproducibility and typically $\pm 10-20$ p.p.m. $(0.000005-0.000010)$. The $\mathrm{Nd}$ isotope ratios were normalized to ${ }^{146} \mathrm{Nd} /{ }^{144} \mathrm{Nd}=0.7219$. The repeat analyses of samples JW97-4 and JW 97-18 were made on separate aliquots of rock powder. The two analyses of the rock standard BCR-I, which are shown as examples from a larger number of BCR-1 runs, were made together with the analyses of JW 97-4 and JW 97-18.

*The depleted mantle model age after DePaolo (1983).

$\dagger \varepsilon_{\mathrm{Nd}}$ values vere calculated assuming present day chondritic values ${ }^{147} \mathrm{Sm} /{ }^{144} \mathrm{Nd}=0.1967$ and ${ }^{143} \mathrm{Nd} /{ }^{144} \mathrm{Nd}=0.512638$. 


\section{Suwalki Anorthosite Massif}

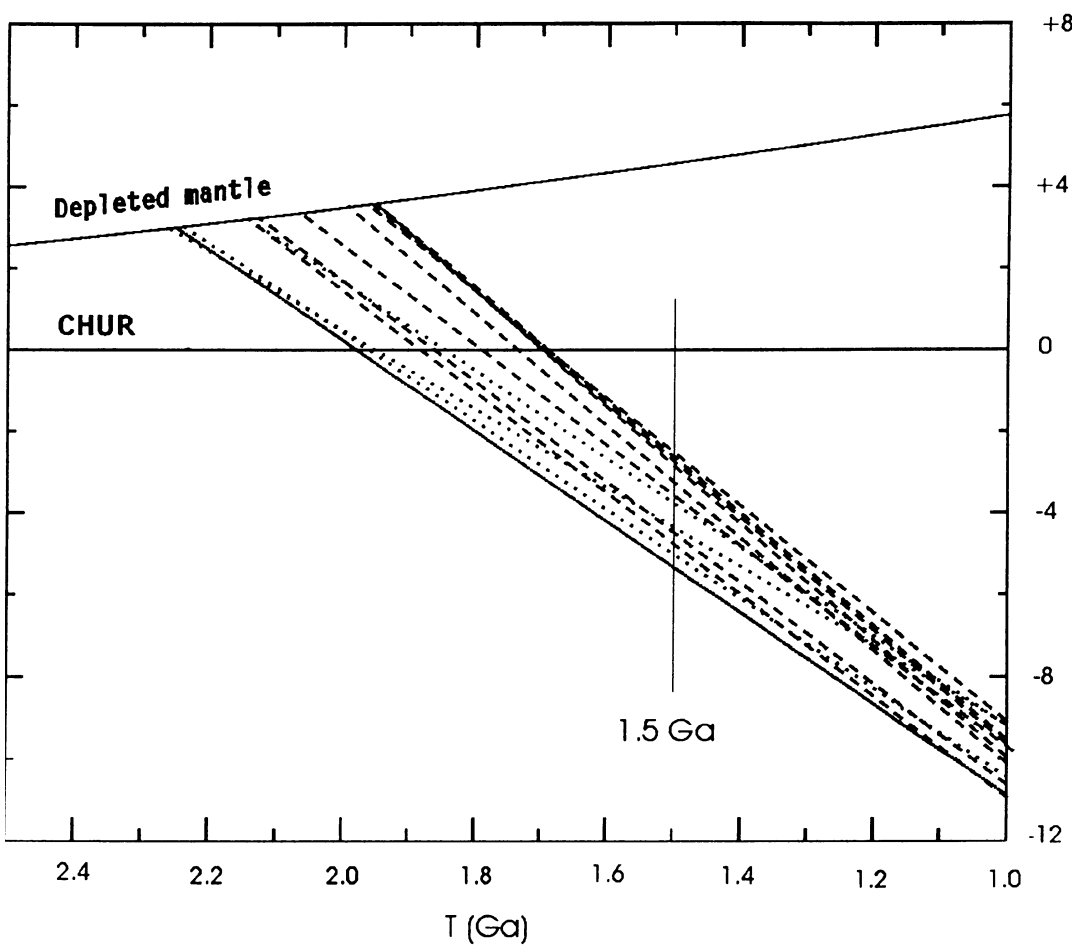

Fig. $6 \varepsilon_{\mathrm{Nd}}$ vs. age for samples of NE Polish anorthosite massifs. The indicated age of $1.5 \mathrm{Ga}$ approximates the intrusive age of the Suwalki massif. Dotted line: jotunite; dashed line: anorthosite; densely dotted line: norite (data in Table 4).

Poland. Polish Geological Institute, pp. 17-19.

Demaiffe, D. and Hertogen, J., 1981. Rare earth element geochemistry and strontium isotopic composition of a massiftype anorthositic - charnockitic body: the Hidra massif (Rogaland, SW. Norway). Geochim. Cosmochim. Acta, $\mathbf{4 5}$, 1545-1561.

DePaolo, D.J., 1983. Geochemical evolution of the crust and mantle. Rev. Geophys. Space Phys., 21, 1347-1358.

Duchesne, J.C., 1987. The Rogaland intrusive massifs: eastern part. In: The Geology of Southermost Norway: an Excursion Guide (C. Maijer and P. Padget, eds), pp. 63-66. Norges geol. Undersøkelse. Special publication no. 1.

Duchesne, J.C. and Hertogen, J., 1988. Le magma parental du lopolithe de Bjerkreim-Sokndal (Norvège méridionale). C.R. Acad. Sci. Paris, 306, 45-48.

Duchesne, J.C., Liégeois, J.P., Vander Auwera, J. and Longhi, J., 1999. The crustal tongue melting model and the origin of massive anorthosites. Terra Nova, 11, 100-105.

Emslie, R.F., 1975. High pressure pyroxene megacrysts from anorthositic rocks and their bearing on the genesis of the parent magma (Abstract). Geol. Soc. Am., Abstract with Progr., 7, 752-753.
Emslie, R.F., 1985. Proterozoic anorthosite massifs. In: The Deep Proterozoic Crust in the North Atlantic Provinces (A.C. Tobi and J.L.R. Touret, eds), pp. 39-60. NATO adv. Stud. Institute, Reidel, Dordrecht.

Emslie, R.F., Hamilton, M.A. and Thiérault, R.J., 1994. Petrogenesis of a MidProterozoic Anorthosite - Mangerite Charnockite - Granite (AMCG) complex: isotopic and chemical evidence from the Nain plutonic suite. J. Geol., 102, 539-558.

Fram, M.S. and Longhi, J., 1992. Phase equilibria of dikes associated with Proterozoic anorthosite complexes. Am. Mineral., 77, 605-616.

Ghiorso, M.S. and Sack, R.O., 1995. Chemical mass balance in magmatic processes IV. A revised and internally consistent thermodynamic model for the interpolation and extrapolation of liquid-solid equilibria in magmatic systems at elevated temperatures and pressures. Contrib. Mineral. Petrol., 119, 197-212.

Hamilton, M.A., Ryan, A.B., Emslie, R.F. and Ermanovics, I.F., 1998. Identification of Paleaoproterozoic anorthosititic and monzonitic rocks in the vicinity of the Mesoproterozoic Nain Plutonic Suite, Labrador: U-Pb Evidence.
Radiogenic Age and Isotopic Studies, Geological Survey of Canada, Current Research 1998-F, Report 11, 23-40.

Hannah, J.L. and Stein, H.J., 2002. Re-Os model for the origin of sulfide deposits in anorthosite-associated intrusive complexes. Econ. Geol., 97, 371-383.

Higgins, M.D. and van Breemen, O., 1992. The age of the Lac-St-Jean anorthosite complex and associated mafic rocks, Grenville Province, Canada. Can. J. Earth Sci., 29, 1412-1423.

Juskowiak, O., 1998. Occurrence, structure and mineral diversity of rocks from the Suwalki anorthosite massif. Prace Panstwowego Instytutu Geologicznego, 61, 53-80.

Kolker, A., Frost, C.D., Hanson, G.N. and Geist, D.J., 1991. Neodymium, strontium, and lead isotopes in the Maloin Ranch pluton, Wyoming: implications for the origin of evolved rocks of anorthosite margins. Geochim. Cosmochim. Acta, 55, 2285-2297.

Kress, V. and Carmichael, I., 1991. The compressibility of silicate liquids containing $\mathrm{Fe}_{2} \mathrm{O}_{3}$ and the effect of composition, temperature, oxygen fugacity and pressure on their redox states. Contrib. Mineral. Petrol., 108, 83-92.

Kubicki, S. and Ryka, W., 1982. Geological Atlas of Crystalline Basement in Polish Part of East European Platform. Wydawiniclwa Geologiczne, Warsaw, Poland.

Longhi, J., Fram, M.S., Vander Auwera, J. and Montieth, J.N., 1993. Pressure effects, kinetics, and rheology of anorthositic and related magmas. Am. Mineral., 78, 1016-1030.

Longhi, J., Vander Auwera, J., Fram, M. and Duchesne, J.C., 1999. Some phase equilibrium constraints on the origin of Proterozoic (Massif) anorthosites and related rocks. J. Petrol., 40, 339-362.

Maquil, R. and Duchesne, J.C., 1984. Géothermométrie par les pyroxènes et mise en place du massif anorthositique d'Egersund-Ogna (Rogaland, Norvège méridionale). Ann. Soc. Géol. Belg., 107, $27-49$.

Mitchell, J.N., Scoates, J.S., Frost, C.D. and Kolker, A., 1996. The geochemical evolution of anorthosite residual magmas in the Laramie Anorthosite Complex, Wyoming. J. Petrol., 37, 637-660.

Morgan, J.W., Stein, H.J., Hannah, J.L., Markey, R.J. and Wiszniewska, J., 2000. $\mathrm{Re}-\mathrm{Os}$ study of Fe-Ti-V oxide and $\mathrm{Fe}-\mathrm{Cu}-\mathrm{Ni}$ sulfide deposits, Suwalki anorthosite massif, northeast Poland. Mineralium Deposita, 35, 391-401.

Owens, B.E., Rockow, M.W., Icenhower, J.P. and Dymek, R.F., 1993. Jotunites from the Grenville Province, Quebec: petrological characteristics and implications for massif anorthosite petrogenesis. Lithos, 30, 57-80. 
Ryka, W. and Podemski, M., 1998. Geology of the Suwalki Anorthosite Massif (Northeastern Poland). Prace Panstwowego Instytutu Geologicznego, Warsaw, Poland.

Schiellerup, H., Lambert, D.D., Prestvik, T., Robins, B., McBride, J.S. and Larsen, R.B., 2000. Re-Os isotopic evidence for a lower crustal origin of massif-type anorthosites. Nature, 405, 781-784.

Scoates, J.S. and Chamberlain, K.R., 1997. Orogenic to post-orogenic origin for the 1.76 Ga Horse Creek anorthosite complex, Wyoming, USA J. Geol., 105, 331343.

Stein, H.J., Morgan, J.W., Markey, R.J. and Wiszniewska, J., 1998. A Re-Os study of the Suwalki anorthosite massif, northeast Poland. Geophys. J., 4, 11-114.

Vander Auwera, J., Bologne, G., Roelandts, I. and Duchesne, J.C., 1998a.
Inductively coupled plasma-mass spectrometry (ICP-MS) analysis of silicate rocks and minerals. Geol. Belg., 1, 40-53.

Vander Auwera, J. and Longhi, J., 1994. Experimental study of a jotunite (hypersthene monzodiorite): constraints on the parent magma composition and crystallization conditions $(\mathrm{P}, \mathrm{T}, \mathrm{fO} 2)$ of the Bjerkreim-Sokndal layered intrusion. Contrib. Miner. Petrol., 118, 60-78.

Vander Auwera, J., Longhi, J. and Duchesne, J.C., 1998b. A liquid line of descent of the jotunite (hypersthene monzodiorite) suite. J. Petrol., 39, 439-468.

Wiebe, R.A., 1979. Fractionation and liquid immiscibility in an anorthositic pluton of the Nain complex, Labrador. J. Petrol., 20, 239-269.

Wiebe, R.A., 1984. Commingling of magmas in the Bjerkrem-Sogndal lopolith
(Southwest Norway): evidence for the compositions of residual liquids. Lithos, 17, 171-188.

Wilmart, E., Demaiffe, D. and Duchesne, J.C., 1989. Geochemical constraints on the genesis of the Tellnes ilmenite deposit (S.W. Norway). Econ. Geol., 84, 10471056.

Wiszniewska, J., 1998. Mineralogy of Fe-Ti-V ores of the Suwalki anorthosite massif. In: Geology of the Suwalki Anorthosite Massif (NE Poland) (W. Ryka and M. Podemski, eds), pp. 137-150. Prace Panstwowego Instytutu Geologicznego, Warsaw, Poland.

Received 8 January 2002; revised version accepted 1 August 2002 